\title{
Thin Layer Mathematical Modelling of Cob Maize in a Natural Convection Solar Drier
}

\author{
M Mukwangole ${ }^{1} \&$ I. N. Simate ${ }^{1}$ \\ ${ }^{1}$ Department of Agricultural Engineering, University of Zambia, Lusaka \\ Correspondence: Mukuwa Mukwangole, Department of Agricultural Engineering, University of Zambia, Lusaka. \\ E-mail: mukuwamukwangole@gmail.com
}

Received: September 23, 2017 Accepted: September 30, 2017 Online Published: October 25, 2017

doi:10.5539/eer.v7n2p37 URL: https://doi.org/10.5539/eer.v7n2p37

\begin{abstract}
A semi- cylindrical natural convection solar tunnel drier (STD) was used for experiments to dry maize cobs that were partially field- dried. The air temperature recorded in the collector unit was higher than ambient temperature by $15.8^{\circ} \mathrm{C}$ to $20.8^{\circ} \mathrm{C}$ and this was effective in reducing the moisture content of maize cobs from $30 \%$ wet basis to safe level storage moisture content of $12.5 \%$ wet basis. Averages of solar radiation recorded during the experiments ranged from $585.6 \mathrm{~W} / \mathrm{m}^{2}$ to $759.8 \mathrm{~W} / \mathrm{m}^{2}$. The averages of relative humidity that prevailed in the drying unit ranged from $6.8 \%$ to $18.2 \%$ whereas the ambient relative humidity averaged from $27.3 \%$ to $43.7 \%$. Drying time was examined with moisture content ratio as exponential and polynomial correlations. Fourteen different drying mathematical models available in literature were compared using their coefficients of determination to estimate solar drying curves. Based on statistical analysis of the results, Midilli drying model had the best fit to the experimental drying data of maize with a coefficient of determination $\mathrm{R}^{2}=0.99912$ as compared to other models.
\end{abstract}

Keywords: natural convection, solar tunnel drier, drying time, maize cobs, mathematical modelling

\section{Introduction}

Maize is Zambia's staple food and is grown widely throughout the country and provides 60 percent of all calories consumed in Zambia (Chisanga et al., 2015). Jazayeri and Amani (2004) reported that maize accounts for over $30 \%$ of lower- income households and contributes $50 \%$ of protein intake. Smallholder maize farmers produce $79 \%$ of Zambia's 1.2 million metric tons annual food requirement (JAICAF, 2008). On average maize production amongst smallholder farmers varies between 1.2 and 1.6 metric tons per hectare (Chiona, 2012).

Once the maize seed has been planted, physiological maturity is attained between 130 and 160 days. This is dependent on the variety. At this stage the crop has a moisture content of about 30 percent, and can be harvested provided that adequate drying facilities are available (EIP-AGRI, 2015). As a result of lacking suitable drying facilities, small-scale farmers are compelled to harvest their maize long after it has reached physiological maturity. EIP-AGRI (2015), reports that harvesting may be delayed by up to two months in order to allow the maize to dry. Delays in harvesting inevitably leads to problems such as exposure to attacks by termites, rodents, domestic animals and infestation by insects.

The traditional practice of drying grain has been to spread the crop on the ground, stooking the maize stalks and drying over fire places. The above mentioned drying techniques leave the crop exposed to the elements of inclement weather (high relative humidity and rainy conditions) and theft. It also delays preparation of the field if a winter crop is to be grown. The crop will not be dried sufficiently if weather conditions are too cloudy and humid and this can result in high losses.

As a result of the challenges associated with open-sun drying, drying grain can be enhanced by utilizing solar energy through the use of solar driers. In this research, a solar tunnel drier using natural convection of air movement was used to dry cob maize with a view to reduce postharvest losses associated with the traditional methods of drying.

Previous work on solar driers include a solar tunnel drier that was developed at the University of Hohenheim, with the purpose of preserving agricultural products by means of drying (Agbossou et al., 2016). According to Mastekbayeva et al. ( 1998) the standard solar tunnel drier is $18 \mathrm{~m}$ long and $2 \mathrm{~m}$ wide. It can be loaded with between 
300 and $500 \mathrm{~kg}$ of goods to be dried. For the current research, a $5-\mathrm{m}$ long by $2-\mathrm{m}$ wide semi- cylindrical natural convection solar tunnel drier was fabricated and used in the experiments. One half of the base plate was painted black and served as the collector and transformed incoming sunlight into heat. In the process the heated air becomes relatively dry and is then displaced by natural convection over the food to be dried, where it takes up moisture and finally exits through the chimney. Incoming sunlight on the drying chamber of the drier additionally helps to evaporate moisture from the foods.

Many studies have been reported on thin-layer drying of agricultural products and food materials (Agbossou et al., 2016, Agarry et al., 2014, Hossain and Bala, 2007, Akpinar et al., 2003). Drying of cereals and fruits has been reported in a considerable number of works (Basunia and Abe, 2001). Literature does not show that any studies have been conducted on thin-layer drying of maize cobs using a natural convection solar tunnel drier. Therefore, the objective of this study is to assess thin-layer drying of maize cobs under natural convection and weather conditions of Zambia.

\section{Materials and Methods}

\subsection{Materials}

The maize cobs used during the drying experiments were grown at the University of Zambia, School of Agricultural Sciences Field Station. The crop was for the 2016/2017 season and the variety used was SEEDCO 513 , which is a medium maturing seed. The maize was harvested manually and taken to the experimental site. Figure 1 below is a picture showing the maize in the field when it had reached physiological maturity.

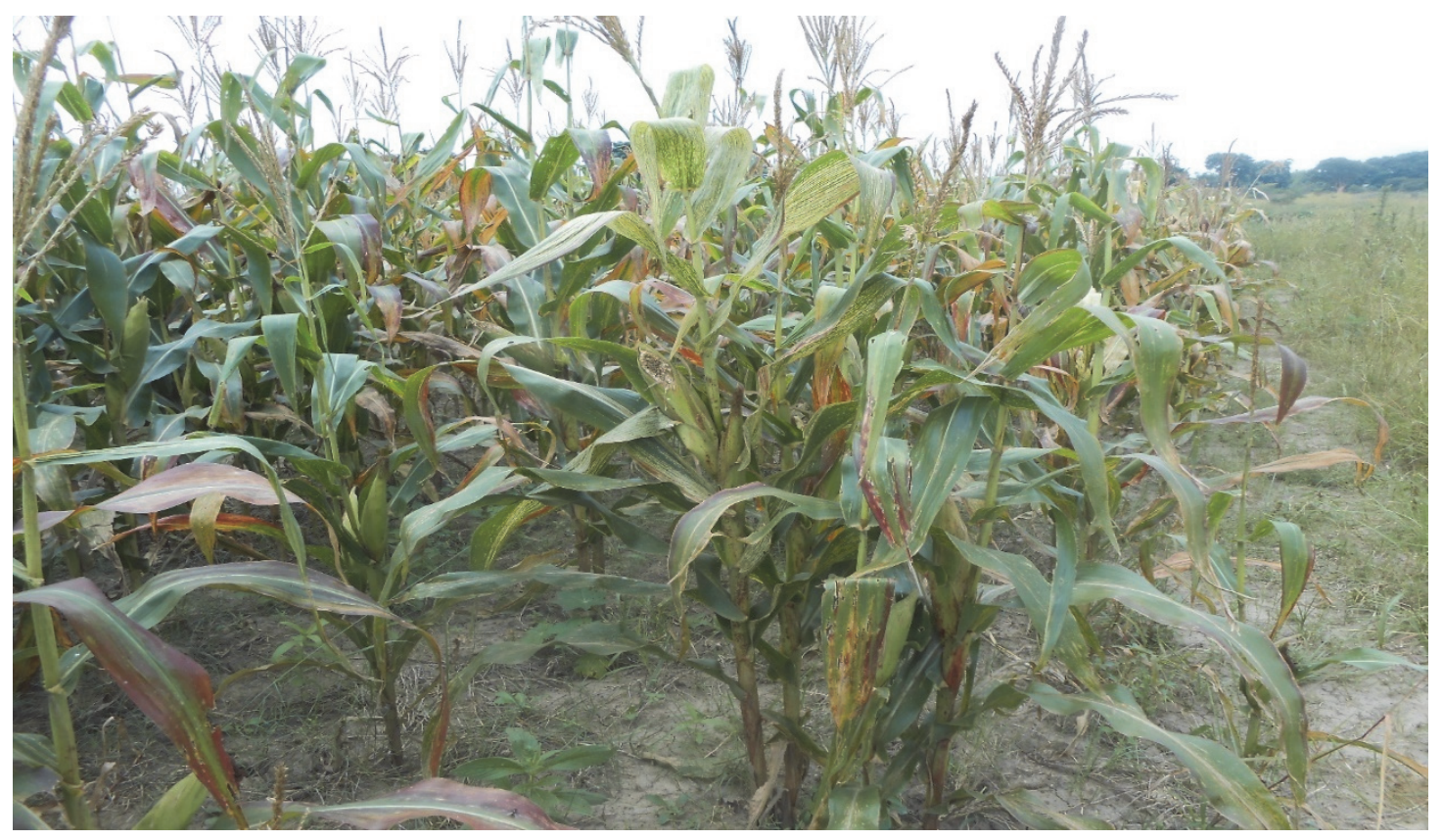

Figure 1. Pictorial view of Maize Field. University of Zambia, Lusaka

\subsection{Experimental Apparatus}

For this work, a semi-cylindrical solar tunnel drier was employed to dry maize cobs. The drier is made up of a flat plate air heating collector unit painted black, a drying chamber and a covered flat plate solar chimney. Ultraviolet treated transparent greenhouse plastic was used to cover the collector, drying chamber and chimney units. The maize cobs were placed on a drying tray in a thin-layer in the drying chamber. Figure 2 below shows a picture of the drier. The entire assembly was positioned on a raised platform, $60 \mathrm{~cm}$ above the ground. Air movement in the drier was achieved through natural convection by buoyant pressure resulting from a temperature difference between the air in the chimney and that in the ambient. 


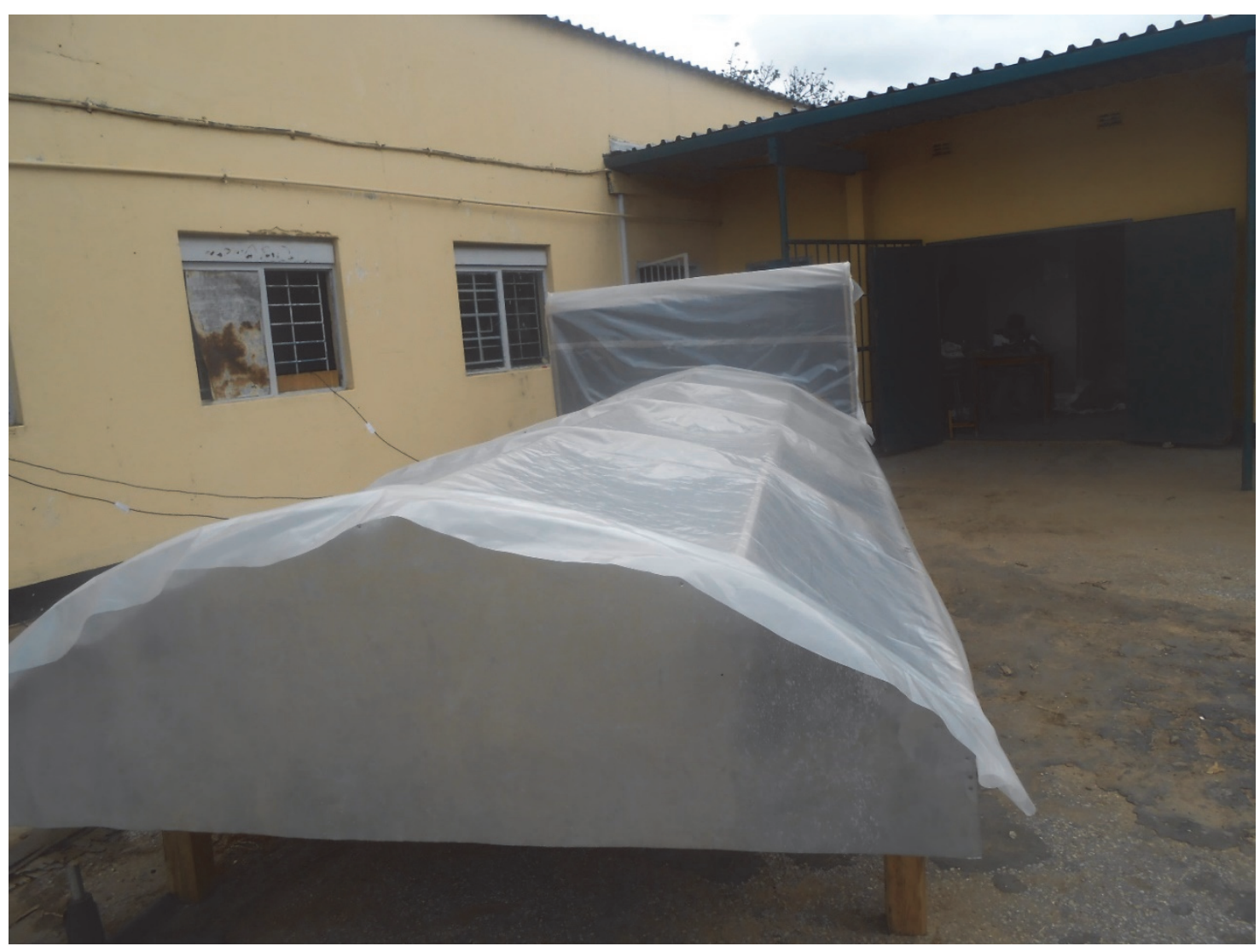

Figure 2. Picture of completed drier

\subsection{Experimental Procedures}

Measurements of temperature were taken at the exit of the air heating collector, the exit of the drying unit and at the exit vent of the chimney using three thermocouples (Campbell Scientific, Model T108, accuracy $\pm 0.2{ }^{\circ} \mathrm{C}$ ). Ambient temperature and ambient relative humidity were measured by a relative humidity probe (Model HMP60-L, accuracy $\pm 0.2-\%$ ) which was placed in open air near the drier. A pyranometer (Kipp and Zonen, Model CM11, accuracy $\pm 0.5 \mathrm{~W} / \mathrm{m}^{2}$ ) was used to measure the intensity of the solar radiation. All these probes were connected to a multi-channel data logger (Campbell Scientific, Model CR1000) which was also connected to a laptop; and readings were taken every minute from the beginning of a drying day at 09:00 hours up to 16:00 hours daily until the maize cobs reached a safe moisture content of $12.5-\%$. Samples of nine cobs were used to measure weight loss every one or two hours. The cobs were placed in such a way that three cobs were in the front, three in the middle and three at the end of the drying unit. A digital balance (Metter, Model PE3000, accuracy $\pm 0.1 \mathrm{~g}$ ) was used to measure the changes in weight of the maize cobs. Having determined the initial moisture content before each experiment, the moisture content at any given time was calculated from the weight of the product samples and the dried solid mass of the samples.

Wind speed was measured using a digital airflow meter (Model TES 1340 , accuracy $\pm 0.1 \mathrm{~m} / \mathrm{s}$ ) at the entry to the drier, the exit of the collector unit, the exit of the drying unit and the exit of the chimney.

For each drying experiment, $134 \mathrm{~kg}$ of maize cobs were placed in the drier. Before each experiment, samples of maize were selected to determine the initial moisture content of the maize cobs. Cobs weighing between $782.0 \mathrm{~g}$ to $1214.7 \mathrm{~g}$ were weighed on a digital balance and then placed in the convective oven (Jeio Tech, Model $\mathrm{ON}-02 \mathrm{G}$, accuracy, $\pm 0.5 \%$ ) set at a temperature of $103^{\circ} \mathrm{C}$ for 72 hours to completely remove the moisture (Loewer et al., 1994) . Figure 3 below shows the maize being dried in the Solar Tunnel Drier (STD). 


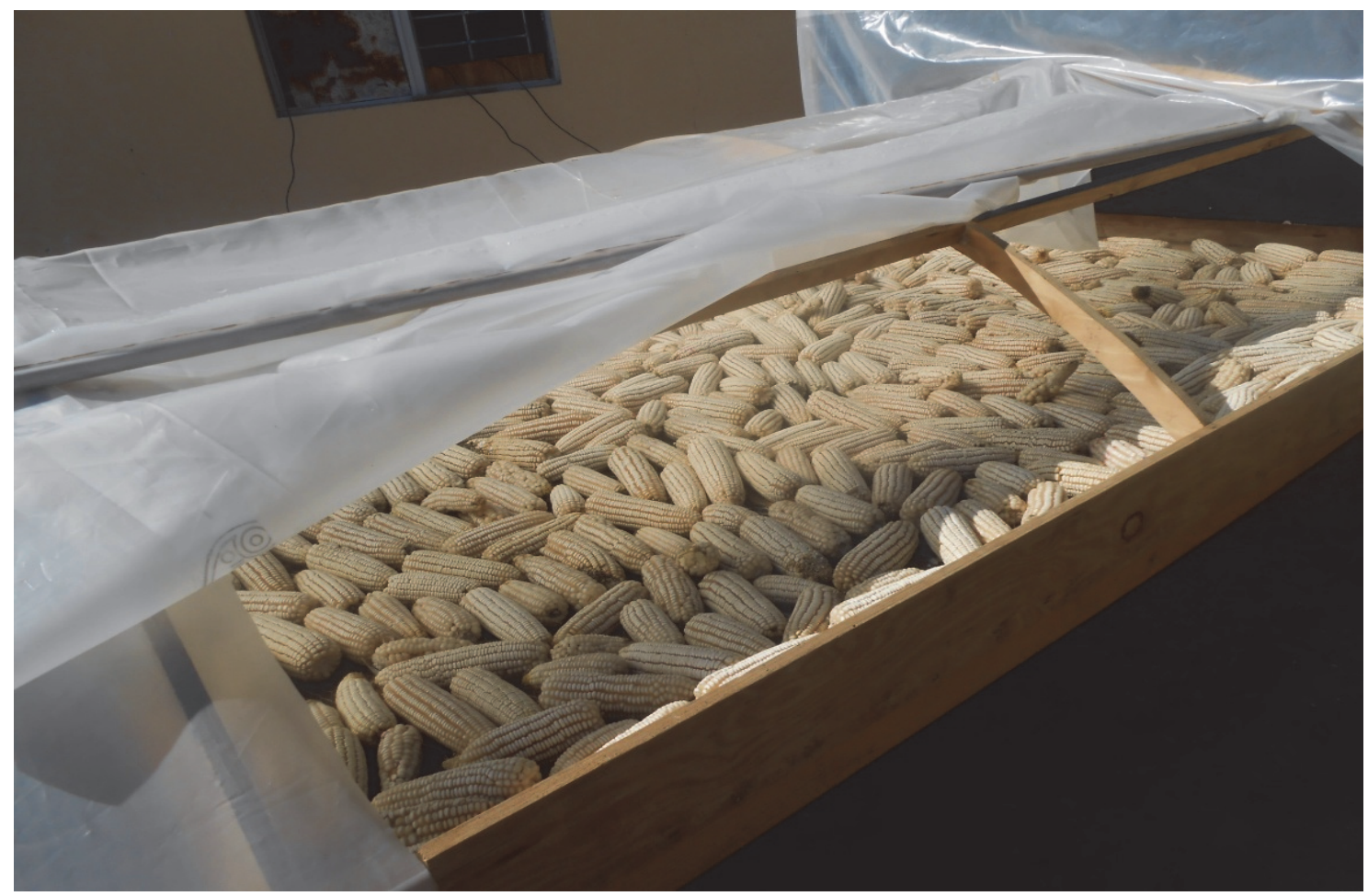

Figure 3. Pictorial view of maize being dried in the drier

\subsection{Mathematical Modelling of Solar Drying Curves}

As the drying process proceeds, the moisture ratio of samples can be expressed by the following equation (1)

$$
\mathrm{MR}=\left(\mathrm{X}_{\mathrm{t}}-\mathrm{X}_{\mathrm{e}}\right) /\left(\mathrm{X}_{\mathrm{o}}-\mathrm{X}_{\mathrm{e}}\right)
$$

MR represents the dimensionless moisture content ratio; $X_{t}, X_{0}$ and $X_{e}$ are the moisture content at any given time, the initial moisture content and the equilibrium moisture content, respectively (Agbossou et al., 2016) .

By using fourteen different mathematical models (Table 1), drying curves were fitted to the experimental data using regression analysis.

Table 1. Mathematical models given by various authors for the solar drying curves

\begin{tabular}{|c|c|c|}
\hline Model No & Model Equations & Model Name \\
\hline 1 & $\mathrm{X}_{\mathrm{t}} / \mathrm{X}_{\mathrm{o}}=\exp (-\mathrm{kt})$ & Newton \\
\hline 2 & $\mathrm{X}_{\mathrm{t}} / \mathrm{X}_{\mathrm{o}}=\exp \left(-\mathrm{kt}^{\mathrm{n}}\right)$ & Page \\
\hline 3 & $\mathrm{X}_{\mathrm{t}} / \mathrm{X}_{\mathrm{o}}=\mathrm{a}^{*} \exp (-\mathrm{kt})$ & Henderson Pabis \\
\hline 4 & $X_{t} / X_{o}=a^{*} \exp (-k t)+c$ & Logarithmic \\
\hline 5 & $X_{t} / X_{0}=a^{*} \exp \left(-k_{1} t\right)+b * \exp \left(-k_{2} t\right)$ & Two-Term \\
\hline 6 & $\mathrm{X}_{\mathrm{t}} / \mathrm{X}_{\mathrm{o}}=1+\mathrm{at}+\mathrm{bt}^{2}$ & Wang and Singh \\
\hline 7 & $X_{t} / X_{o}=a^{*} \exp (-k t)+(1-a) \exp (-k a t)$ & Two-Term Exponential \\
\hline 8 & $\mathrm{X}_{\mathrm{t}} / \mathrm{X}_{\mathrm{o}}=\exp \left[-(\mathrm{kt})^{\mathrm{n}}\right]$ & Modified Page \\
\hline 9 & $X_{t} / X_{0}=a^{*} \exp (-k t)+(1-a) \exp (-g t)$ & Verma et al. \\
\hline 10 & $X_{t} / X_{o}=a^{*} \exp (-k t)+(1-a) \exp (-k b t)$ & Yaldiz and Ertekin \\
\hline 11 & $\mathrm{X}_{\mathrm{t}} / \mathrm{X}_{\mathrm{o}}=\exp \left(-\mathrm{k}\left(\mathrm{t} / \mathrm{I}^{2}\right)^{\mathrm{n}}\right)$ & Modified Page \\
\hline 12 & $\mathrm{X}_{\mathrm{t}} / \mathrm{X}_{\mathrm{o}}=1+\mathrm{at}+\mathrm{bt}^{2} \mathrm{ct}^{3}$ & Gokhan GURLEK \\
\hline 13 & $X_{t} / X_{o}=a^{*} \exp \left(-k t^{n}\right)+b t$ & Midilli et al. \\
\hline 14 & $X_{t} / X_{o}=a^{*} \exp (-k t)+b * \exp (-g t)+c * \exp (-h t)$ & Modified Henderson and Pabis \\
\hline
\end{tabular}

Source: (Agbossou et al., 2016)

In this study, the theoretical model employed is dependent on Fick's law. It takes into consideration the 
geometric shape of a sphere, ignores the grain volumetric variation and considers the known moisture condition at the surface of the grain.

\subsection{Data Analysis}

To determine the statistical parameters regression analysis was performed by employing the Excel Solver-add in, which is a statistical computer programme. The moisture ratio (MR) was reduced to $X / X_{\mathrm{o}}$ as opposed to $\left(X_{t}-X_{e}\right) /$ $\left(X_{o}-X_{e}\right)$ (Diamante and Munro, 1993, Yaldiz et al., 2001a).

The reduced $X$ - square, root mean square error (RMSE) and modelling efficiency (EF) were used as the primary criteria to select the best equation to account for variation in the drying curves of the dried samples (Ozdemir and Devres, 1999, Yaldiz et al., 2001b, Gupta et al., 2013). To determine the goodness of fit, the reduced X-square, which is the mean square of the deviations between the experimental and calculated values, was used. Lower values of the reduced $X$ - square indicate a better goodness of fit. The RMSE gives the deviation between the predicted and experimental values and it is required to reach zero. The modelling efficiency (EF) gives the model's ability and its highest value is 1 . To calculate these statistical values, the formulae given below were used:

$$
\begin{aligned}
& X^{2}=\underline{\Sigma}_{\underline{i=1}}^{N}\left(M^{N} \underline{\text { exp }, \mathrm{i}} \underline{\left.-M R_{p r e, i}\right)^{2}}\right. \\
& \mathrm{N}-\mathrm{n}
\end{aligned}
$$

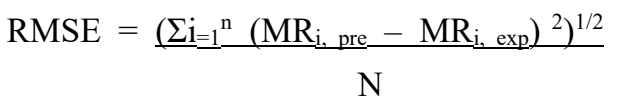

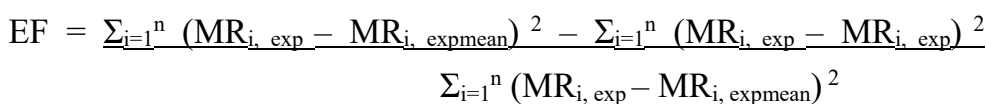

where $\mathbf{M R}_{\mathbf{e x p}, i}$ is the experimental moisture ratio found in any measurement and $\mathbf{M R}_{\text {pre }, i}$ is predicted moisture ratio for this measurement. $\mathrm{N}$ and $\mathrm{n}$ are the number of observations and constants respectively (Pangavhane et al., 1999, Sarsavadia et al., 1999).

\section{Results and Discussion}

The changes in the ambient air temperature, relative humidity and solar intensity during the experimentation are shown in Figure 4 for a typical day of May 2017 in Lusaka, Zambia. The daily average values of ambient air temperature, relative humidity and solar intensity registered during the experiments ranged from 23.1 to $26.9{ }^{\circ} \mathrm{C}$, 38.9 to $55.7 \%$ and 343.4 to $534.0 \mathrm{~W} / \mathrm{m}^{2}$, respectively. The maximum ambient temperature was recorded at 13:30 hours with a value of $27.7^{\circ} \mathrm{C}$; the lowest relative humidity was recorded at the same time with a value of $36.9 \%$, whereas the maximum solar radiation was registered at 11:30 hours with a value of $822.9 \mathrm{~W} / \mathrm{m}^{2}$.

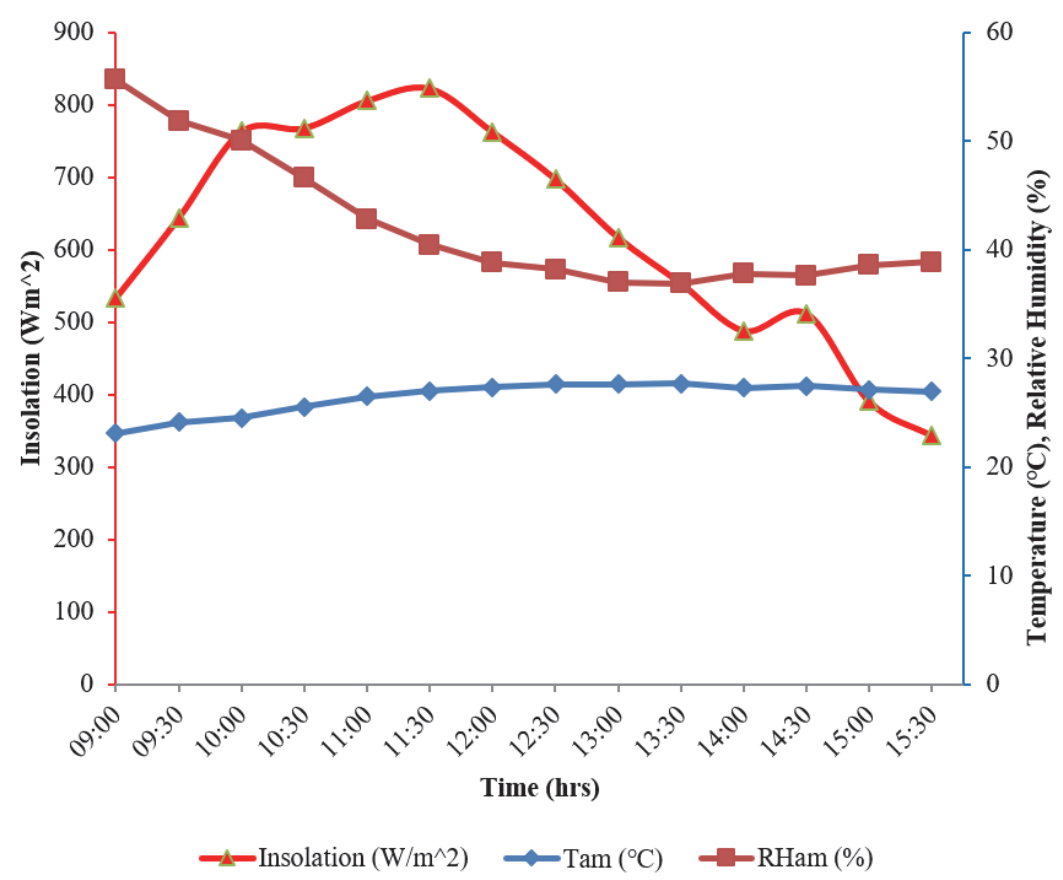

Figure 4. Variation of ambient air temperature, ambient relative humidity and solar radiation with time 
Figure 5 shows variation of air temperature and relative humidity with time at different positions of the tunnel drier. It can be seen that ambient temperature was lowest followed by the temperature of air exiting the chimney. The temperatures of the air exiting the collector and the drying unit were not very different. This can be attributed to the fact that the product did not have free moisture associated with the constant drying rate period. It can be observed that collector and drying unit temperatures were highest at 12:30 hours when a temperature of $50.6{ }^{\circ} \mathrm{C}$ was attained as opposed to $27.6{ }^{\circ} \mathrm{C}$ for ambient temperature giving a difference of $23{ }^{\circ} \mathrm{C}$. The drier retains heat from the solar radiation received. The collector and drying units' temperatures remained high despite the solar intensity reducing as the day progressed.

These results show a close relation to the result for chilly drying in farm solar drier and for grape drying in solar tunnel (Vijaykumar et al., 2012, Vijaykumar et al., 2010 , Desai et al., 2009).

The graph also shows that the ambient relative humidity remained high during the drying experiment with highest value recorded at 09:00 hours reading 55.7\%. The relative humidity in the collector and drying units did not vary much as the drying progressed with values of 32.1\% and 28 \% recorded at 09:00 hours, respectively. In the chimney, the relative humidity was lower than the ambient one. The relative humidity continued reducing until later in the day when it started increasing despite the decrease in solar intensity.

There is a direct relation showing that the higher the drier and collector unit temperatures, the lower the relative humidity in the same units. A mean drying unit temperature of $45.6{ }^{\circ} \mathrm{C}$ was attained while the mean ambient temperature was $26.4{ }^{\circ} \mathrm{C}$. Whereas the mean ambient relative humidity was $42.2 \%$, in the drying unit it was $15.7 \%$. A mean temperature of $18.8^{\circ} \mathrm{C}$ above ambient was attained in the collector unit.

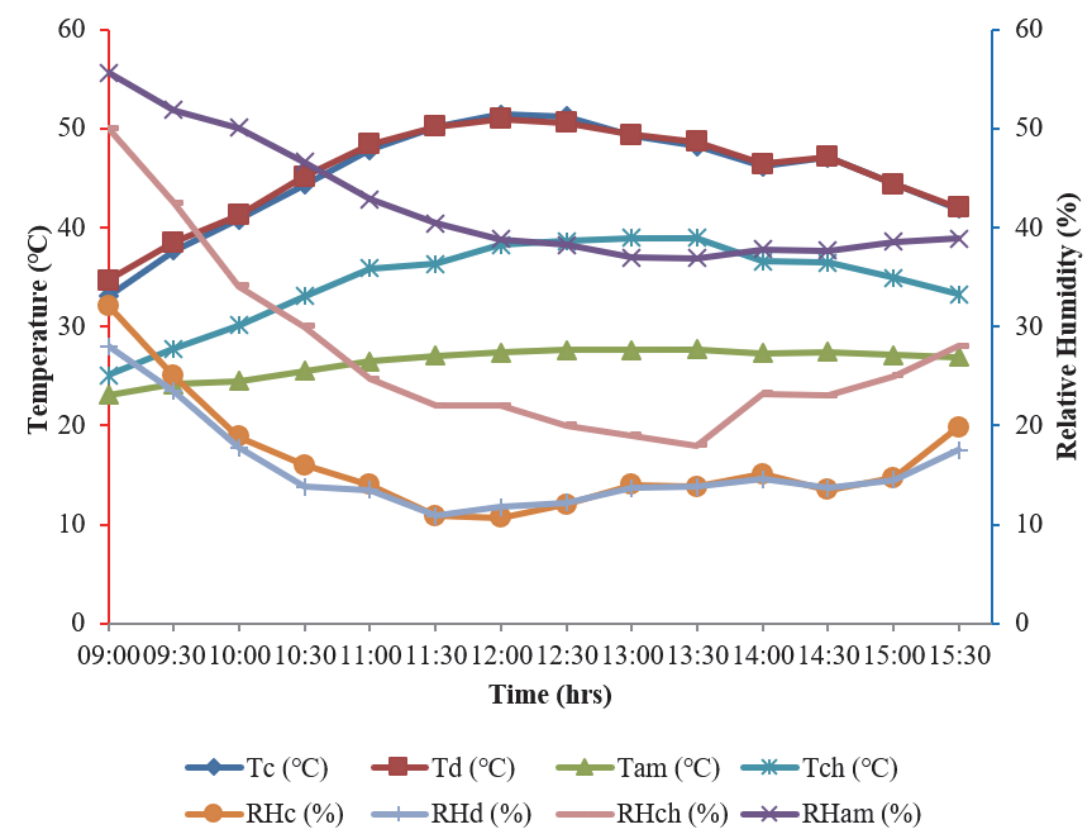

Figure 5. Variation of temperature and relative humidity over the drying period

Figures, 6 and 7 show the moisture content and moisture ratio respectively, with time. It took 48 hours to reach a moisture content of $12.6 \%$ in the Solar Tunnel Drier (STD) as opposed to 76 hours in Open Sun Drying (OSD), resulting in a saving of $37 \%$ drying time when using a STD. 


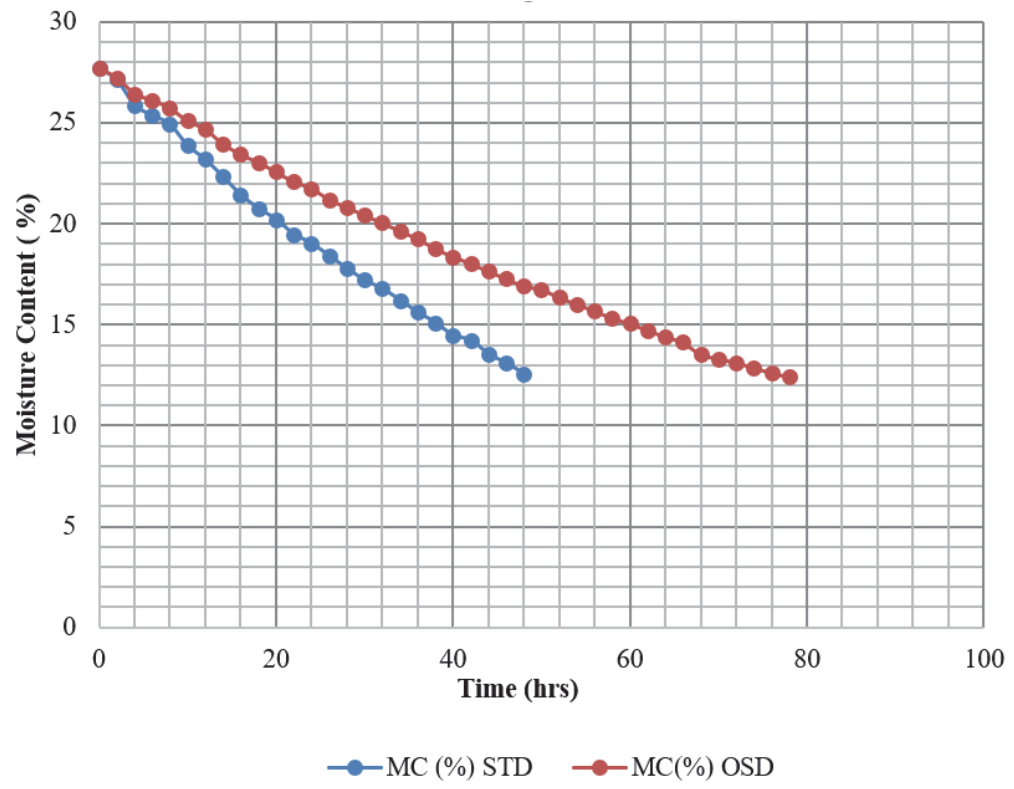

Figure 6. Reduction of moisture content over drying time

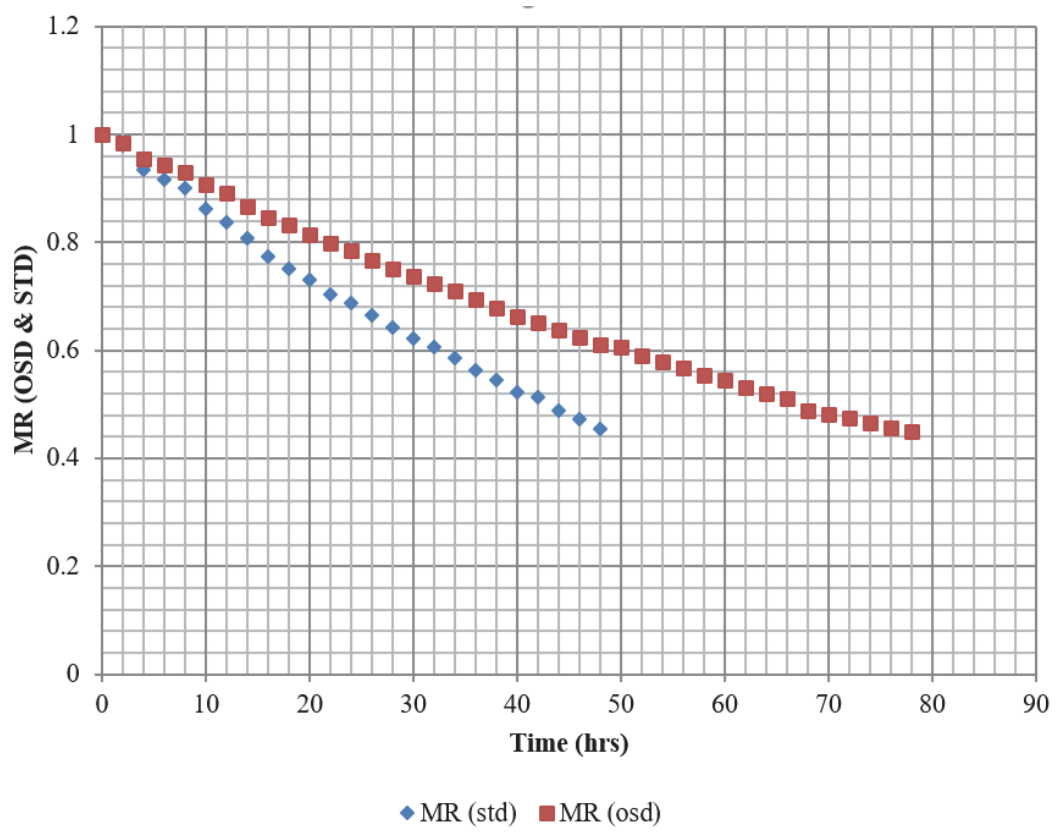

Figure 7. Fluctuation of moisture ratio in open-sun drying (OSD) and solar tunnel drying (STD) over drying period

In order to authenticate the goodness of fit of each model to the generated data during the maize drying at different ambient variation temperatures, statistical parameters were obtained. These parameters are shown in Table 2 below. 
Table 2. The statistical parameters obtained in order to verify the fit of each model to the observed data during the maize drying at different ambient variation temperatures. (Models arranged in order of best fitting)

\begin{tabular}{|c|c|c|c|c|c|}
\hline Model Name & \multicolumn{2}{|c|}{ Constants } & $x^{2}$ & RMSE & $\mathbf{R}^{2}$ \\
\hline 13. Midilli et al & $\mathbf{a}$ & 1.001941 & $2.82 \mathrm{E}-05$ & 0.004869 & 0.999122485 \\
\hline & $\mathbf{k}$ & 0.013655 & & & \\
\hline & $\mathbf{n}$ & 1.046508 & & & \\
\hline & b & $4.82 \mathrm{E}-05$ & & & \\
\hline \multicolumn{6}{|c|}{ 8. Modified Page Equation } \\
\hline & $\mathbf{k}$ & 0.021592 & $2.72 \mathrm{E}-05$ & 0.0048918 & 0.999114262 \\
\hline & I & 1.259918 & & & \\
\hline \multirow{3}{*}{ 2. Page Model } & $\mathbf{n}$ & 1.052231 & & & \\
\hline & $\mathbf{k}$ & 0.01328 & $2.60 \mathrm{E}-05$ & 0.0048918 & 0.999114261 \\
\hline & $\mathbf{n}$ & 1.052186 & & & \\
\hline \multirow[t]{3}{*}{ 4. Logarithmic } & $\mathbf{a}$ & 1.144151 & $2.73 \mathrm{E}-05$ & 0.0049028 & 0.999110268 \\
\hline & $\mathbf{k}$ & 0.013586 & & & \\
\hline & c & -0.13898 & & & \\
\hline
\end{tabular}

\section{Modified Henderson and Pabis}

\begin{tabular}{|c|c|c|c|c|c|}
\hline & a & 0.237395 & $3.28 \mathrm{E}-05$ & 0.004992 & 0.999077585 \\
\hline & $\mathbf{k}$ & 0.023088 & & & \\
\hline & b & -0.02295 & & & \\
\hline & g & 0.254449 & & & \\
\hline & c & 0.784921 & & & \\
\hline & $\mathbf{h}$ & 0.014966 & & & \\
\hline \multirow[t]{2}{*}{ 9. Verma et al. } & $\mathbf{a}$ & 1.014971 & $2.87 \mathrm{E}-05$ & 0.0050232 & 0.999066044 \\
\hline & $\mathbf{k}$ & 0.016422 & & & \\
\hline \multirow{5}{*}{ 5. Two-Term } & g & 0.550595 & & & \\
\hline & $\mathbf{a}$ & -0.01398 & 3.09E-05 & 0.0050966 & 0.999038545 \\
\hline & $\mathbf{k}_{1}$ & 0.906538 & & & \\
\hline & b & 1.013869 & & & \\
\hline & $\mathbf{k}_{2}$ & 0.016386 & & & \\
\hline \multirow[t]{2}{*}{ 12. Gokhan GURLEK } & $\mathbf{a}$ & -0.01483 & 3.03E-05 & 0.0051616 & 0.999013861 \\
\hline & b & $7.70 \mathrm{E}-05$ & & & \\
\hline \multirow{3}{*}{ 6. Wang and Singh } & c & $-7.60 \mathrm{E}-08$ & & & \\
\hline & a & -0.01476 & $2.90 \mathrm{E}-05$ & 0.005166 & 0.999012179 \\
\hline & b & $7.21 \mathrm{E}-05$ & & & \\
\hline \multicolumn{6}{|l|}{ 3. Henderson and Pabis } \\
\hline & $\mathbf{a}$ & 1.010462 & $3.45 \mathrm{E}-05$ & 0.0056348 & 0.998824757 \\
\hline & k & 0.016267 & & & \\
\hline 1. Newton Model & $\mathbf{k}$ & 0.015896 & $5.49 \mathrm{E}-05$ & 0.0072622 & 0.998047864 \\
\hline \multicolumn{6}{|l|}{ 7. Two -Term Exponential } \\
\hline & $\mathbf{a}$ & 1.000001 & $5.73 \mathrm{E}-05$ & 0.0072622 & 0.998047864 \\
\hline \multirow{3}{*}{ 10. Yaldiz and Ertekin } & $\mathbf{k}$ & 0.015896 & & & \\
\hline & a & 0.004571 & $6.66 \mathrm{E}-05$ & 0.0076559 & 0.997830469 \\
\hline & k & 0.080356 & & & \\
\hline \multirow{3}{*}{ 11. Modified Page } & b & 0.196296 & & & \\
\hline & k & 0.0175 & 0.000739 & 0.0260662 & 0.974850606 \\
\hline & $\mathbf{n}$ & 1 & & & \\
\hline
\end{tabular}

The drying data as the moisture ratio (MR) versus drying time were fitted to fourteen mathematical models. Figure 8 shows the result of regression analysis done using the Excel Solver add-in computer programme and the variation of moisture ratio versus drying time for Midilli mathematical model. 


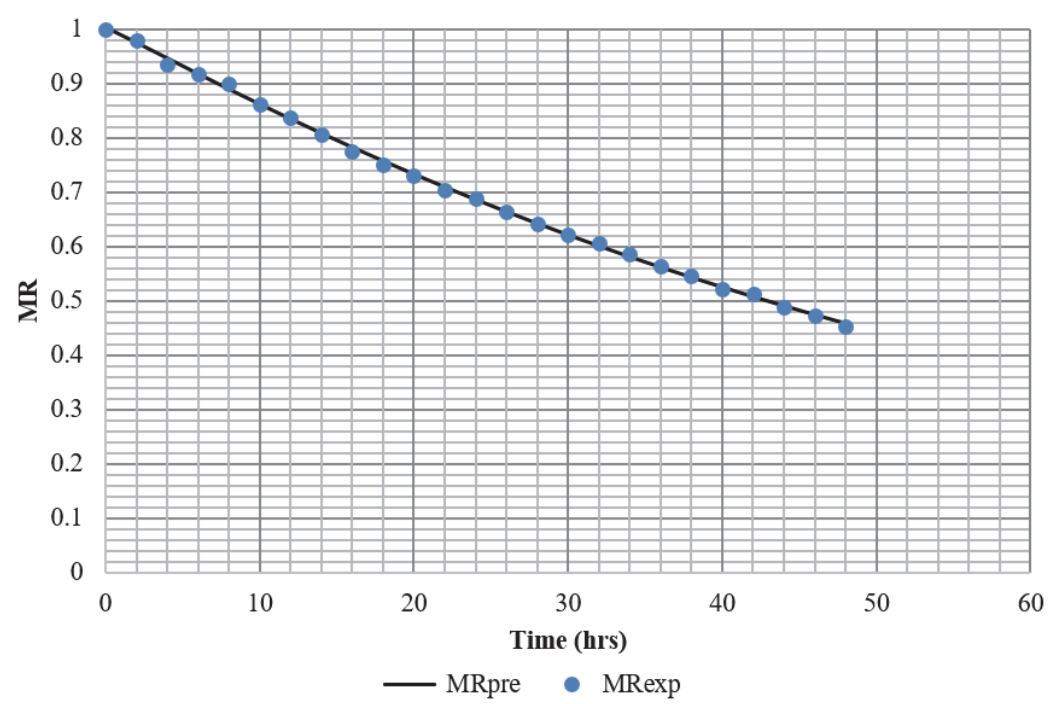

Figure 8. Result of regression analysis for Midilli mathematical model (STD)

From Table 2, all the models $\mathrm{R}^{2}$ were greater than 0.9 indicating their acceptability (Madamba et al., 1996). The constants and coefficients of the accepted model for the solar tunnel drying of maize cobs are shown below.

$\mathrm{R}^{2}=0.99912 ; \mathrm{RMSE}=0.004869 ; \mathrm{X}^{2}=2.82 * 10^{-05}$.

$\mathrm{a}=1.001941 ; \mathrm{k}=0.013655 ; \mathrm{n}=0.013655 ; \mathrm{b}=4.82 \mathrm{E}-05$

The Midilli model provided a good conformity between experimental and predicted moisture ratios. The experimental data generally grouped (that is, almost all points lying on the straight line) around the curve for the predicted moisture ratio. This shows the credibility of this model in describing solar drying characteristics of maize cobs.

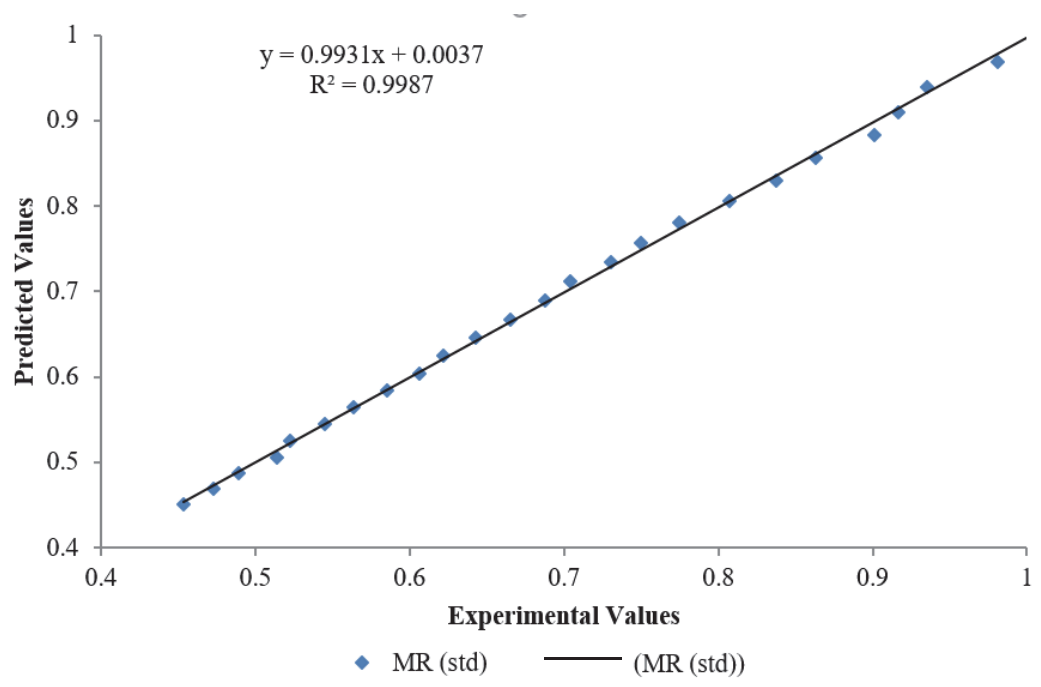

Figure 9. Experimental and Predicted MR

\section{Conclusion}

This study has revealed that the semi- cylindrical natural convection solar tunnel drier can successfully be used for drying maize cobs. All the drying of the maize cobs took place in the falling rate period as the cobs had lost all the free moisture before being harvested. The maize dried in the solar tunnel was protected from dust contamination, insects and birds.

Fourteen different mathematical models were fitted to thin-layer experimental drying data in order to explain the drying behaviour of maize cobs. These models were compared according to their statistical parameters: $\mathrm{R}^{2}$, 
RMSE and $x^{2}$. From the results of thin layer drying of maize cobs, the Midilli et al model was found as the best model which could be used to predict the moisture content of the product.

\section{Acknowledgement}

I am grateful to the Zambia National Service Command for all the support rendered and to the School of Agricultural Sciences at University of Zambia for allocating me a portion where the maize for experiments was grown.

\section{Nomenclature}

$\begin{array}{ll}\mathrm{a}, \mathrm{b}, \mathrm{c}, \mathrm{n} & \text { Empirical coefficients in drying models } \\ \mathrm{EF} & \text { Modelling efficiency } \\ \mathrm{a}, \mathrm{b}, \mathrm{c}, \mathrm{d}, \mathrm{h}, \mathrm{g}, \mathrm{k}, & \text { Empirical constants in drying models } \\ \mathrm{X} \mathrm{t} & \text { Sample mass in time (kg moisture / kg dry matter) } \\ \mathrm{MR} & \text { Moisture ratio } \\ \text { MRexp } & \text { Moisture ratio experimental } \\ \text { MRpred } & \text { Moisture ratio predicted } \\ \mathrm{n} & \text { Number of constants in the model } \\ \mathrm{N} & \text { Number of observations } \\ \text { Exp } & \text { Experimental result } \\ \text { RMSE } & \text { Root mean square error } \\ \mathrm{R}^{2} & \text { Coefficient of correlation } \\ \mathrm{X}^{2} & \text { Reduced chi-square } \\ \text { STD } & \text { Solar tunnel drier } \\ \text { OSD } & \text { Open-sun drying } \\ \text { SEEDCO } & \text { Seed company }\end{array}$

\section{References}

Agarry, S. E., Afolabi, T. J., \& Akintunde, T. T. Y. (2014). Modelling the Water Absorption Characteristics of Different Maize (Zea Mays) Types during Soaking. J. Food Process Technol, 5.

Agbossou, K., Napo, K., \& Chakraverty, S. (2016). Mathematical Modelling and Solar Tunnel Drying Characteristics of Yellow Maize. American Journal of Food Science and Technology, 4, 115-124.

Akpinar, E. K., Midilli, A., \& Bicer, Y. C. (2003). Single layer drying behavior of potato slices in a convective cyclone and mathematical modeling.

Basunia, M. A., \& Abe, T. (2001). The thin -layer solar drying characteristics of rough rice under natural convection. Journal of Food Engineering, 47, 295-301.

Chiona, S. (2012). Technical And Allocative Efficiency of Smallholder Maize. Farmers In Zambia Master of Science in Agricultural Economics Dissertation, University of Zambia.

Chisanga, C. B., Phiri , E., Shepande, C., \& Sichingabula, H. (2015). Evaluating CERES-Maize Model Using Planting Dates and Nitrogen Fertilizer in Zambia. Journal of Agricultural Science, 7(19).

Desai, S. R., Vijaykumar, P., \& Anantachar, M. (2009). Performance evaluation of farm solar dryer for chilly drying. Karnantaka J. Agric. Sci., 22, 382-384.

Diamante, L. M., \& Munro, P. A. (1993). Mathematical modelling of the thin layer solar drying of sweet potato slices. Solar Energy, 51, 271-276.

Eip-Agri. (2015). Solar Maize $\quad$ Dryer. $\quad$ Retrieved from https://ec.europa.eu/eip/agriculture/en/content/solar-maize-dryer.

Gupta, A., Shukla, S. K., \& Srivastava, A. K. (2013). Analysis of solar drying unit with phase change material storage systems. Int. J. Agile Systems and Management, 6, 164-174.

Hossain, M., \& Bala, B. K. (2007). Thin-Layer Drying Characteristics for Green Chilli.

JAICAF. (2008). The Maize in Zambia and Malawi. 
Jazayeri, S. M. H. M., \& Amani, R. (2004). Nutritional Knowledge, Attitudes and Practices of Bodybuilding Trainers in Ahwaz, Iran. Pakistan Journal of Nutrition, 3, 228-231.

Loewer, O. J., Bridges, T. C., \& Bucklin, R. A. (1994). Principles of Drying. On-Farm Drying and Storage Systems. American Society of Agricultural Engineers.

Madamba, P. S., Driscoll, R. H., \& Buckle, K. A. (1996). The thin-layer drying characteristics of garlic slices. Journal of food engineering, 29 75-97.

Mastekbayeva, G. A., Leon, M. A., \& Kumar, S. (1998). Performance Evaluation Of A Solar Tunnel Dryer For Chilli Drying. ASEAN Seminar \& Workshop on Drying Technology. Phitsanulok, Thailand.

Ozdemir, M., \& Devres, Y. O. (1999). The thin layer drying characteristics of hazelnuts during roasting. Journal of Food Engineering, 42, 225-233.

Pangavhane, D. R., Sawhney, R. L., \& Sarsavadia, P. N. (1999). Effect of various dipping pretreatment on drying kinetics of Thompson seedless grapes. Journal of Food Engineering, 39, 211-216.

Sarsavadia, P. N., Sawhney, R. L., Pangavhane, D. R., \& Singh, S. P. (1999). Drying behaviour of brined onion slices. Journal of Food Engineering, 40, 219-226.

Vijaykumar, P., Desai, S. R., Lokesh, M., \& Anatachar, M. (2012). Performance evaluation of solar Tunnel dryer for chilly drying. Karnataka j. Agric. Sci., 25, 472-474.

Vijaykumar, P., S.R., D., Anatachar, M., Yaranal, R. S., \& Shankar, W. (2010). Grapes drying in solar tunnel drying-an approach In: Proc.of 23 rd Nation. . Convention of Agricultural Engineers held at MPKV, 2010 Rahuri.

Yaldiz, O., Ertekin, C., \& Uzun, H. I. (2001a). Mathematical modeling of thin layer solar drying of sultana grapes. Energy, 26, 457-465.

Yaldiz, O., Ertekin, C., \& Uzun, H. I. (2001b). Mathematical modelling of thin layer solar drying of Sultana grapes. Energy Convers Mgmt, 26, 457-465.

\section{Copyrights}

Copyright for this article is retained by the author(s), with first publication rights granted to the journal.

This is an open-access article distributed under the terms and conditions of the Creative Commons Attribution license (http://creativecommons.org/licenses/by/4.0/). 